\title{
De Belgische socialisten en de Hongaarse opstand
}

Piet Creve, departement Archief AMSAB

De internationale politieke actualiteit van 1956 werd voor een groot deel beheerst door de toenemende spanningen in het Midden-Oosten die in de herfst uitmondden in de Brits-Frans-Israëlische interventie in Egypte. Toch beroerde de Suez-crisis de gemoederen veel minder dan de nagenoeg gelijktijdige gebeurtenissen in Hongarije.

Op het twintigste congres van de communistische partij van de Sovjet-Unie in de zomer van 1956 hadden de opvolgers van Stalin hun voorganger van zijn voetstuk gehaald. Onder de leiding van het Kremlin werden veranderingen binnen het communistische systeem mogelijk en zelfs aangemoedigd, zowel in de Sovjet-Unie als in de andere Oostbloklanden.

Maar in Hongarije verloor de partijleiding de greep op het hervormingsproces. Eind oktober kwam deSovjet-Unie voor het eerst en nog op beperkte schaal tussen. De dynamiek was evenwel niet gestopt. Geconfronteerd met eisen als het verlaten van het $W$ arschaupact grepen de machthebbers op het Kremlin een tweede keer in. Op 4 november kwamen Russische troepen massaal in actie.

In België vonden nagenoeg alle politieke partijen elkaar in hun krachtige veroordeling van de Russische interventie. In de Senaat ondertekenden de fractievoorzitters van socialisten, liberalen en christen-democraten samen een motie in die zin. Maar in de Kamer kregen de socialisten kritiek uit CVP-hoek. Dat eerste minister Van Acker en minister van buitenlandse zaken Spaak vóór de Hongaarse opstand in de Sovjet-Unie waren geweest en een cultureel akkoord hadden ondertekend, werd omschreven als hypocrisie.

Het CVP-kamerlid Dupont verweet de socialisten in Hongarije vrijheid en democratie te verdedigen en tegelijkertijd die waarden in België uit te hollen. De socialistische pers reageerde heftig en verontwaardigd. In Le Peuple weerlegde Albert Housiaux de aantijgingen en beschuldige sommige CVP-kringen van "une basse manoeuvre partisane destinée à salir le Premier ministre et Paul-Henri Spaak." (1)

Op de bureauvergadering van 30 oktober betuigde de BSP-leiding haar solidariteit met het Hongaarse volk "in hun strijd voor de nationale onafhankelijkheid en voor de democratische vrijheden" ${ }^{(2)}$. Ook andere socialistische organisaties zoals het ABVV, de Jongsocialisten en de Socialistische Vooruitziende Vrouwen, spraken in resoluties hun afkeuring van de gebeurtenissen uit en verklaarden zich solidair met de opstandelingen.

Net als in de reacties buiten de socialistische beweging stonden de begrippen "vrijheid" en "democratie" centraal in het socialistische discours. Maar de socialisten spaarden zich geen moeite om het specifieke van hun opstelling te verduidelijken. Zij distancieerden zich zowel van een blind anti-communisme als van een kritiekloze pro-communistische houding. Dat laatste lijkt evident. Hoewel het communisme als binnenlandse politiek opponent en concurrent ter linkerzijde aan electorale sterkte had ingeboet, 


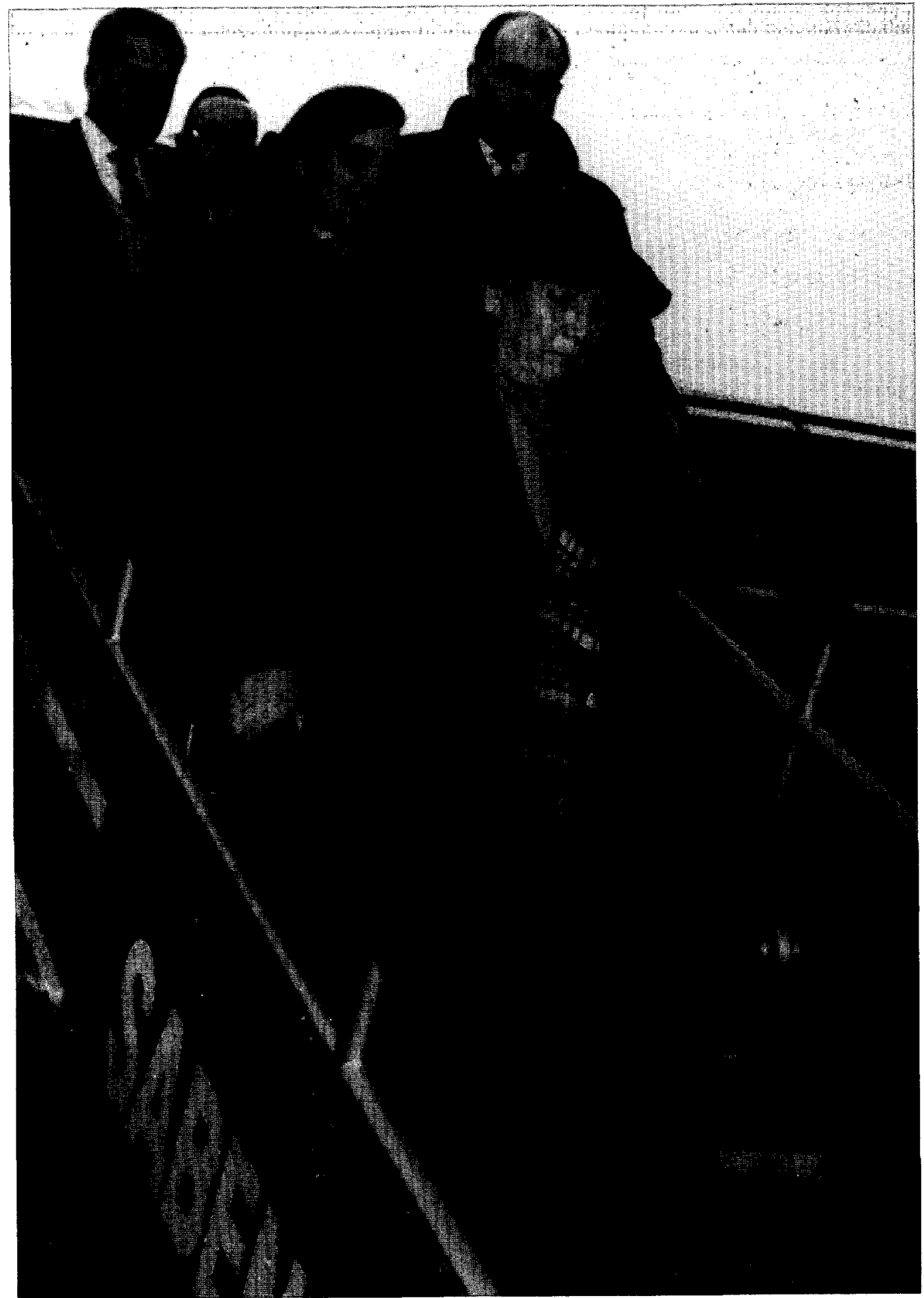

Aankomst van Anna Ketbly in Melsbroek op invitatie van de BSP (26 november 1956) 
bleef het een algemene ideologische vijand. Dat de socialisten zich niet wilden laten inschakelen in een anti-communistische campagne, blijkt bijvoorbeeld uit een perscommuniqué van het ABVV dat de Hongaarse opstand koppelt aan de Brits-Frans-Israëlische operatie tegen Egypte en waarin het bureau "namens de arbeidersklasse elke toevlucht tot oorlog of tot het gewapend geweld om conflicten te regelen, veroordeelt en het zelfbeschikkingsrecht van elk volk benadrukt." (3) De socialistische opstelling sloot aan bij wat in socialistische middens al langer werd gepropageerd als "de derde weg", een maatschappelijk model tussen kapitalisme en communisme. In die context krijgt de analyse van de gebeurtenissen in Hongarije een specifieke invulling, zoals ook een editoriaal in de Vooruit duidelijk maakt: de arbeiders vergieten hun bloed voor vrijheid en sociale rechtvaardigheid, voor het socialisme dus. Die inschatting onderscheidt de socialistische reactie van "al wat reactionair is in het Westen" en geeft tegelijk het vanzelfsprekende aan van socialistische solidariteit ${ }^{(4)}$. Of anders gesteld: voor de socialisten werden in Hongarije vrijheid en democratie, basisvoorwaarden voor het ware socialisme, op brute wijze onderdrukt.

De solidariteit bleef niet bij woorden. Onder de kop "Arbeiders uit alle landen, verenigt U ! Helpt het Hongaarse Volk." riep het Socialistisch Steunfonds de arbeiders op het Hongaarse volk te steunen met niet-bederfbare levensmiddelen, dekens en klederen. De gewestelijke bureaus van de organisatie fungeerden als verzamelpunten en het hoofdbureau zorgde voor het transport. Geld kon gestort worden met de vermelding "Voor het vrije Hongarije" (5). Later zou de organisatie instaan voor de opvang van ongeveer 900 Hongaarse vluchtelingen.

Op 29 oktober publiceerde Vooruit de eerste oproep voor financiële steun. De dag erna besliste het bureau van het ABV 100.000 frank te storten, vandaag ongeveer 5 miljoen. Het bureau riep de centrales op ook een financiële inspanning te doen. Het ACOD maakte eenzelfde bedrag vrij en stelde voor dat het ABVV de opvang van Hongaarse kinderen zou stimuleren en meer bepaald "de plaatsing van deze kinderen in arbeiderfamilies" ${ }^{(6)}$. Deze oproep refereert zowel aan de opvang van Spaanse kinderen als gevolg van de burgeroorlog, als aan die van Hongaarse kinderen die het slachtoffer waren van de binnenlandse troebelen die volgden op de onafhankelijkheid na de Eerste Wereldoorlog.

De concrete hulp beperkte zich niet tot het humanitaire vlak. Er werd ook gewerkt aan hulp voor de Hongaarse socialisten die opnieuw een politieke en syndicale werking hadden ontplooid. Zo had Arthur Gailly, voorzitter van CMB-Charleroi, zich gebogen over de vakbondsproblemen aldaar ${ }^{(7)}$. Anna Kethly, de legendarische leidster van de Hongaarse socialisten, kon met logistieke steun van de socialisten een persconferentie houden in Brussel over de situatie in haar land en werd daarna door de BSP gehuldigd ${ }^{(8)}$.

De socialistische reacties op de Hongaarse opstand waren deels politiek en vooral ideologisch gemotiveerd, maar gingen ook verder. Ze bleven evenmin beperkt tot de leiding van de diverse socialistische organisaties, maar maakten heel wat betrokkenheid aan de basis vrij. Voor de socialisten waren de gebeurtenissen een gelegenheid om zowel het eigen maatschappijmodel te verdedigen als om concrete solidariteit te tonen.
(1) Le Peuple, 15 november 1956.
(2) Vooruit, 31 oktober 1956.
(3) AMSAB, archief ABV (nr. 144), 296: bureauvergade- ring van 6 november 1956 .
(4) Vooruit, 30 oktober 1956.
(5) AMSAB, archief SM Het Licht (nr. 17), 148/1.
(6) AMSAB, archief ABVV (nr. 144), 296: bureauvergade- ring van 6 november 1956 .
(7) Vooruit, 3 november 1956
(8) Vooruit, 30 november 1956. 